\title{
Flow injection analysis of paracetamol using a biomimetic sensor as a sensitive and selective amperometric detector
}

\author{
Mariana C. Q. Oliveira, ${ }^{a}$ Marcos R. V. Lanza, ${ }^{b}$ Auro A. Tanaka ${ }^{c}$ and Maria D. P. T. Sotomayor ${ }^{* a}$ \\ Received 3rd December 2009, Accepted 24th February 2010 \\ First published as an Advance Article on the web 16th March 2010 \\ DOI: $10.1039 / b 9 a y 00283 a$
}

This work describes the coupling of a biomimetic sensor to a flow injection system for the sensitive determination of paracetamol. The sensor was prepared as previously described in the literature (M. D. P. T. Sotomayor, A. Sigoli, M. R. V. Lanza, A. A. Tanaka and L. T. Kubota, J. Braz. Chem. Soc., 2008, $19,734)$ by modifying a glassy carbon electrode surface with a Nafion ${ }^{\circledR}$ membrane doped with iron tetrapyridinoporphyrazine (FeTPyPz), a biomimetic catalyst of the P450 enzyme. The performance of the sensor for paracetamol detection was investigated and optimized in a flow injection system (FIA) using a wall jet electrochemical cell. Under optimized conditions a wide linear response range $(1.0 \times$ $10^{-5}$ to $\left.5.0 \times 10^{-2} \mathrm{~mol} \mathrm{~L}^{-1}\right)$ was obtained, with a sensitivity of $2579( \pm 129) \mu \mathrm{A} \mathrm{L} \mu \mathrm{mol}^{-1}$. The detection

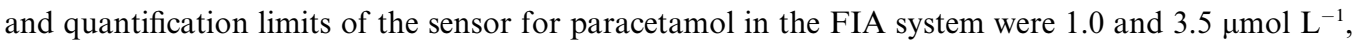
respectively. The analytical frequency was 51 samples $h^{-1}$, and over a period of five days (320 determinations) the biosensor maintained practically the same response. The system was successfully applied to paracetamol quantification in seven pharmaceutical formulations and in water samples from six rivers in São Paulo State, Brazil.

\section{Introduction}

Pharmaceutical substances and personal care products have recently been recognized as an important class of organic pollutants due to their physical-chemical properties, which allow their persistence and bioaccumulation in the environment, provoking negative effects in aquatic or terrestrial ecosystems at concentrations as low as a few nanograms per liter. ${ }^{1-3}$

Many studies have reported the presence of a large number of pharmaceuticals, such as anti-inflammatories, analgesics, $\beta$ blockers, lipid regulators, antibiotics, anti-epileptics and estrogens, at average concentrations in the $\mu \mathrm{g} \mathrm{L}^{-1}$ range, in sewage treatment plant effluents, surface and groundwater and even in drinking water, ${ }^{4-9}$ indicating their poor degradability in sewage treatment plants. ${ }^{5,8,9}$

Concern about pharmaceuticals has often focused on antibiotics, which may promote resistance in natural bacterial populations, and on hormones, which may induce estrogenic responses as well as alterations in the reproduction or development of aquatic organisms. ${ }^{1,2,10,11}$ Wastewaters are the main disposal route of pharmaceuticals into the environment. Nevertheless, other different sources of pharmaceutical release can be proposed to explain the appearance of these xenobiotics in waters and soils, such as inadequate treatment of manufacturing waste, direct disposal of unconsumed drugs in households and

\footnotetext{
${ }^{a}$ Analytical Chemistry Department, Institute of Chemistry, São Paulo State University (UNESP), 14800-900 Araraquara, SP, Brazil. E-mail: mpilar@iq.unesp.br; Tel: +55-16-33016620

${ }^{b}$ Department of Molecular Chemistry and Physics, University of São Paulo, 13560-970 São Carlos, SP, Brazil

${ }^{c}$ Center of Physical Sciences and Technology, Federal University of Maranhão, 65085-580 São Luís, MA, Brazil
}

the use of manure for topsoil dressing. ${ }^{1,4,5,10}$ These compounds are considered as a new category of persistent pollutants. ${ }^{3}$

There is therefore interest in the development of simple, sensitive, selective and reliable methods for the determination of these chemicals, not only in the aquatic environment, but also during production of pharmaceuticals and in dissolution studies. $^{12}$

Paracetamol (acetaminophen, $N$-acetyl- $p$-aminophenol, 4-acetamidophenol or tylenol) is included in this new class of environments pollutants. It is widely used for young children, old people, and in pregnancy as an antipyretic and analgesic drug, to control mild to moderate pain or reduce fever. Its action is similar to that of aspirin, so it is an appropriate alternative for patients who are sensitive to acetylsalicylic acid. ${ }^{13}$

Thus, it is very important to establish fast, simple and accurate methodologies for the detection of paracetamol in quality control analyses (in pharmaceutical formulations), for medical control (in biological fluids such as urine, blood or plasma) and more recently for application in environment control in samples from sewage treatment plant effluents, surface and groundwater and even in drinking water. ${ }^{14}$ It is known that overdose ingestions of acetaminophen can lead to accumulation of toxic metabolites, which may cause severe and sometimes fatal hepatotoxicity and nephrotoxicity. ${ }^{15-17}$

Many analytical methodologies, using both batch and flow modes, have been proposed for the determination of paracetamol, including titrimetry, ${ }^{18}$ spectrophotometry (spectrofluorimetry, near infrared reflectance spectrometry, Raman spectrometry and Fourier transform infrared spectrophotometry), ${ }^{19-26}$ chromatography, ${ }^{27,28}$ chemiluminescence ${ }^{29-31}$ and enzymatic analysis. ${ }^{32,33}$ Electrochemical methods ${ }^{34-36}$ are an attractive alternative, since they are fast, inexpensive, and can be adapted for portable, disposable and miniaturized applications. 
Paracetamol can be readily oxidized at carbon paste or glassy carbon electrodes,${ }^{37}$ however these amperometric procedures are non-selective, since the potential involved in this process ranges from 0.6 to $0.8 \mathrm{~V}$, and various substances are electroactive in this potential interval. However, use of modified electrodes, such as biosensors ${ }^{32,37}$ and more recently biomimetic sensors, ${ }^{38}$ can enable operation at potentials much lower than those normally used, thus decreasing the interference. ${ }^{37}$

Flow injection analysis (FIA) has been routinely used since its inception to provide automated control of sample handling. ${ }^{39}$ FIA involves the injection of a reproducible sample volume into a continuously flowing carrier solution, followed by quantification at a detector device. In addition to automated control, FIA offers other advantages including convective mass transport, matrix exchange and increased precision. The combination of FIA with electrochemical and selective sensors is an attractive tool because of the flexibility of the former and the diagnostic power of the latter. ${ }^{40}$ Flow-through electrochemical sensors allow the continuous real-time monitoring of analytes, and are among the most important types of analytical tools that have received extensive attention, in pharmaceutical analysis as well as in other environmental and biochemical applications. ${ }^{13,37,40,41}$

This paper reports on the development of the first (as far as we are aware) biomimetic sensor coupled to a FIA system for analysis of paracetamol in pharmaceutical formulations and aquatic samples.

\section{Experimental}

\section{Chemicals and solutions}

All chemicals used in the construction and application of the sensor were analytical grade reagents. All chemicals used in the chromatographic experiments were high performance liquid chromatography (HPLC) grade reagents.

The biomimetic complex, iron(III) tetrapyridinoporphyrazine (FeTPyPz), was prepared and purified as previously described. ${ }^{42}$

Acetic acid and $N, N$-dimethylformamide (DMF) were acquired from Synth (São Paulo, Brazil). Paracetamol (acetaminophen) was obtained from Sigma (St. Louis, USA). 5\% $(\mathrm{m} / \mathrm{v}) \mathrm{Nafion}^{\circledR}$ solution was from Aldrich (Milwaukee, USA). Sodium acetate was acquired from Merck (Darmstadt, Germany), and all HPLC grade solvents were from Tedia (Rio de Janeiro, Brazil).

Paracetamol and acetate buffer solutions were prepared with water purified in a Millipore Milli-Q system, and the $\mathrm{pH}$ was determined using an Orion ${ }^{\circledR} \mathrm{pH}$ meter (Model 3 Star $\mathrm{pH}$ ).

\section{Biomimetic sensor construction}

The biomimetic sensor was constructed as previously described. ${ }^{38}$ First, a solution containing $5 \mathrm{mg} \mathrm{mL}^{-1}$ of the FeTPyPz in DMF was prepared. Then, the surface of a glassy carbon (GC) electrode (Metrohm ${ }^{\circledR}$, Switzerland), with a geometrical area of $0.126 \mathrm{~cm}^{2}$, was cleaned according to the procedure described in the literature ${ }^{43}$ After cleaning the electrode, $100 \mu \mathrm{L}$ of FeTPyPz solution was mixed with $50 \mu \mathrm{L}$ of $5 \%(\mathrm{~m} / \mathrm{v})$ Nafion ${ }^{\circledR}$ solution, and an aliquot of $50 \mu \mathrm{L}$ of this mixture placed on the surface of the electrode. Finally, the solvent was evaporated at room temperature during $6 \mathrm{~h}$, forming a thin green film.

\section{Flow manifold and electrochemical measurements}

The biomimetic sensor was inserted into a flow-through wall-jet amperometric cell and used as the working electrode (Fig. 1). An $\mathrm{Ag} \mid \mathrm{AgCl}\left(\mathrm{KCl}_{\text {sat }}\right)$ electrode was the reference, and a platinum wire was the auxiliary electrode. The electrodes were connected to a potentiostat (Palm-sense ${ }^{\circledR}$, Palm Instruments BV, The Netherlands) interfaced to a microcomputer for potential control and data acquisition.

A peristaltic pump (Ismatec ${ }^{\circledR}$ ) was used to provide the flow of the $0.1 \mathrm{~mol} \mathrm{~L}^{-1}(\mathrm{pH} 3.6)$ acetate buffer carrier solution. The standards and samples containing paracetamol were injected into the carrier using a sliding central bar sampling valve. ${ }^{44}$

\section{HPLC analysis}

In order to validate the results obtained using the proposed sensor, they were compared to those obtained using a chromatographic method based on HPLC. ${ }^{45}$ Chromatographic analyses were performed using a Shimadzu ${ }^{\circledR}$ Model 20A liquid chromatograph coupled to an UV/Vis detector (SPD-20A), autosampler (SIL-20A) and a degasser DGU-20A5, controlled by a personal computer. A C18 column $(250 \times 4.6 \mathrm{~mm}$, ShimPack CLC-ODS) was used, inside an oven (Shimadzu ${ }^{\circledR}$ CTO10AS) maintained at $30{ }^{\circ} \mathrm{C}$. The mobile phase was a mixture of methanol and water in a ratio of $13: 87(\mathrm{v} / \mathrm{v})$. The flow rate was $1.0 \mathrm{~mL} \mathrm{~min}{ }^{-1}$, the sample injection volume $20 \mu \mathrm{L}$, and the detector absorption wavelength $254 \mathrm{~nm}$.

\section{Pharmaceutical formulation analysis}

Quantification of paracetamol in seven commercial samples was carried out according to the external standards method. Samples of four commercial solutions were analyzed after simple dilution with deionized water, without additional treatment. These were: Paracetamol (Ache $®$, Lot L0804193, validity 08/10), labeled value of $200 \mathrm{~g} \mathrm{~L}^{-1}$ (1.32 $\mathrm{mol} \mathrm{L}^{-1}$ paracetamol); Tylenol ${ }^{\circledR}$ for children (Janssen-Cilag, Lot LFL169, 04/10), fruit flavor with labeled value of $160 \mathrm{mg}$ of paracetamol for each $5 \mathrm{~mL}$ of syrup; Tylenol ${ }^{\circledR}$ in drops (Janssen-Cilag, Lot FL121, 04/11), labeled value of $200 \mathrm{~g} \mathrm{~L}^{-1}$; Tylenol ${ }^{\circledR}$ for babies, concentrated oral

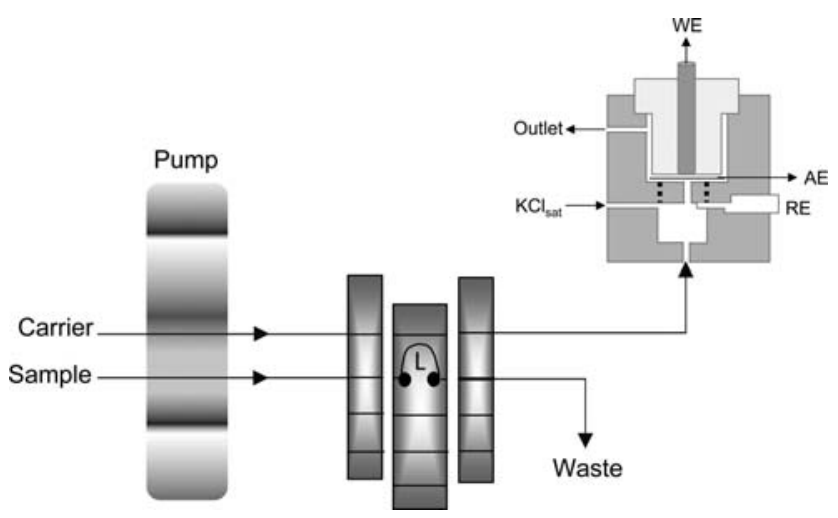

Fig. 1 Schematic diagram of the flow injection system for amperometric determination of paracetamol. L: sample loop $(75 \mu \mathrm{L})$; WE: working electrode (biomimetic sensor); AE: auxiliary electrode (platinum); RE: home-made $\mathrm{Ag} \mid \mathrm{AgCl}\left(\mathrm{KCl}_{\text {sat }}\right.$ reference electrode). 
suspension (Janssen-Cilag, LAL008, 11/09), fruit flavor with labeled value of $100 \mathrm{~g} \mathrm{~L}^{-1}$ of paracetamol. Three additional samples of tablets were also analyzed: Tylenol ${ }^{\circledR}$ DC (JanssenCilag, Lot LCL008, 01/11), labeled value per tablet of $500 \mathrm{mg}$ of paracetamol and $65 \mathrm{mg}$ of caffeine; Tylenol ${ }^{\circledR}$ AP (Janssen-Cilag, Lot LFL105, 02/10), labeled value per tablet of $650 \mathrm{mg}$ of paracetamol; Paracetamol (EMS®, Lot L15655, 05/10), labeled value of $750 \mathrm{mg}$ of paracetamol per tablet.

\section{Aquatic sample analysis}

Six water samples from rivers in São Paulo State, Brazil, were enriched with paracetamol and then analyzed using the proposed sensor in order to evaluate the matrix effect on recovery values.

\section{Results and discussion}

\section{Biomimetic sensor for paracetamol}

The optimization and performance, in batch mode, of the biomimetic sensor used in this work has been reported previously. ${ }^{38}$ Table 1 provides the characteristics of this sensor, where the FeTPyPz complex acts as a biomimetic catalyst of the P450 enzyme. ${ }^{46}$

The sensitivity, operational stability and response time shown by the sensor in batch mode indicated that the device should be able to be satisfactorily coupled to a flow system. Thus, in the next step the sensor was installed in a FIA system shown in Fig. 1. An advantage of flow conditions is that the electrochemical products are more efficiently removed from the electrode surface, avoiding poisoning of the sensor and increasing its lifetime. ${ }^{47}$ Further experiments, using the FIA system, were performed in order to optimize parameters including flow rate, injected sample volume $\left(V_{\mathrm{i}}\right)$ and applied potential.

Table 1 Analytical and kinetic parameters obtained for paracetamol determination using the biomimetic sensor based on the FeTPyPz catalyst in the batch mode. ${ }^{38}$

\begin{tabular}{|c|c|}
\hline Parameter & Response \\
\hline Linear range/mol L ${ }^{-1}$ & $4.0 \times 10^{-6}$ to $4.2 \times 10^{-4}$ \\
\hline Sensitivity $/ \mu \mathrm{A} \mathrm{L} \mathrm{mol}{ }^{-1}$ & $5798 \pm 73$ \\
\hline Correlation coefficient & $0.9994(n=10)$ \\
\hline Detection limit/ $\mu \mathrm{mol} \mathrm{L} \mathrm{L}^{-1}$ & 1.2 \\
\hline Quantification limit $/ \mu \mathrm{mol} \mathrm{L}^{-1}$ & 4.0 \\
\hline $\begin{array}{l}\text { Measurement repeatability }\left(\mathrm{RSD}^{a} \text {, }\right. \\
n=7 \text { and }[\text { Paracetamol] }=2.4 \times \\
\left.10^{-4} \mathrm{~mol} \mathrm{~L}^{-1}\right)\end{array}$ & 3.4 \\
\hline $\begin{array}{l}\text { Reproducibility in the construction } \\
\left.\text { of the sensors ( } \operatorname{RSD}^{a}, n=4\right)\end{array}$ & 5.0 \\
\hline $\begin{array}{l}\text { Applied potential }[\mathrm{mV} v s \\
\left.\quad \mathrm{Ag} \mid \mathrm{AgCl}\left(\mathrm{KCl}_{\mathrm{sat}}\right)\right]\end{array}$ & 450 \\
\hline Response time/s & 0.5 \\
\hline Sensor lifetime/days & 180 \\
\hline $\begin{array}{l}\text { Operational stability/ } \\
\text { measurements }\end{array}$ & 50 (kept $95 \%$ of the initial signal) \\
\hline $\begin{array}{l}\text { Paracetamol diffusion coefficient/ } \\
\mathrm{cm}^{2} \mathrm{~s}^{-1}\end{array}$ & $1.066 \times 10^{-6}$ \\
\hline $\begin{array}{l}\text { Apparent Michaelis-Menten } \\
\text { constant }\left(\mathrm{K}_{\mathrm{M} M}^{\text {app }}\right) / \mathrm{mol} \mathrm{L}^{-1}\end{array}$ & $2.15 \times 10^{-2} \mathrm{~mol} \mathrm{~L}^{-1}$ \\
\hline
\end{tabular}

\section{FIA system optimization}

Optimization of the applied potential was necessary because a home-made $\mathrm{Ag} \mid \mathrm{AgCl}\left(\mathrm{KCl}_{\text {sat }}\right)$ reference electrode was used in the wall jet cell. Fig. 2 shows the results obtained under flow conditions. The maximum response of the sensor was achieved at an applied potential of $500 \mathrm{mV}$, thus this potential was selected during subsequent experiments. Although, in the batch system, ${ }^{1}$ higher sensitivity was obtained at $450 \mathrm{mV}$ vs. a commercial $\mathrm{Ag} \mid \mathrm{AgCl}\left(\mathrm{KCl}_{\text {sat }}\right)$ electrode (Table 1), under flow conditions a small increment of $+50 \mathrm{mV}$ was observed.

The flow rate dependence of the signal response of the biomimetic sensor can be seen in Fig. 3. The signal response for paracetamol increases up to a flow rate of $1.25 \mathrm{~mL} \mathrm{~min}^{-1}$ because mass transfer, accompanied by electronic transfer, increases with increasing flow rate. The subsequent decrease in the signal response with increased flow rate is due to limitations of the chemical reaction, since as the sample passes through the electrode faster, the fraction of the substrate oxidized by its chemical reaction with the FeTPyPz is smaller. This behavior can be explained considering the short response time $(0.5 \mathrm{~s})$, and the

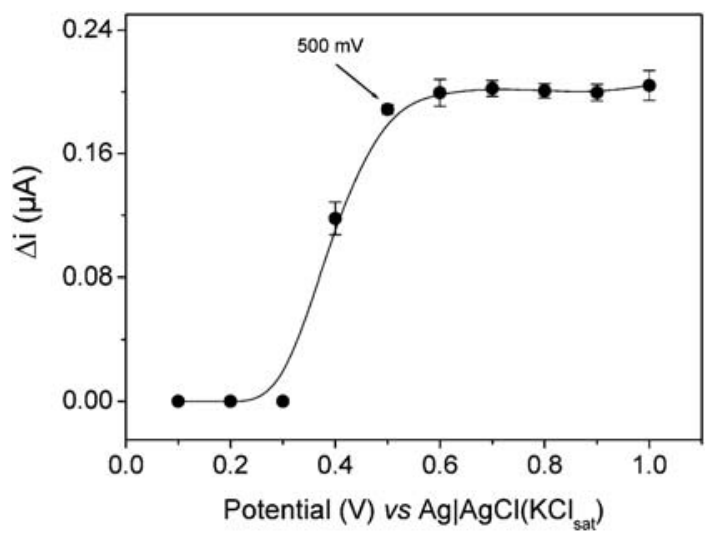

Fig. 2 Influence of the applied potential on the response to $1.0 \times 10^{-4}$ mol L ${ }^{-1}$ paracetamol, with $V_{\mathrm{i}}$ of $75 \mu \mathrm{L}$, flow rate of $1.25 \mathrm{~mL} \mathrm{~min}^{-1}$ and using a $0.1 \mathrm{~mol} \mathrm{~L}^{-1}$ acetate buffer at $\mathrm{pH} 3.6$ as carrier. The error bars correspond to the standard deviation for seven replicates.

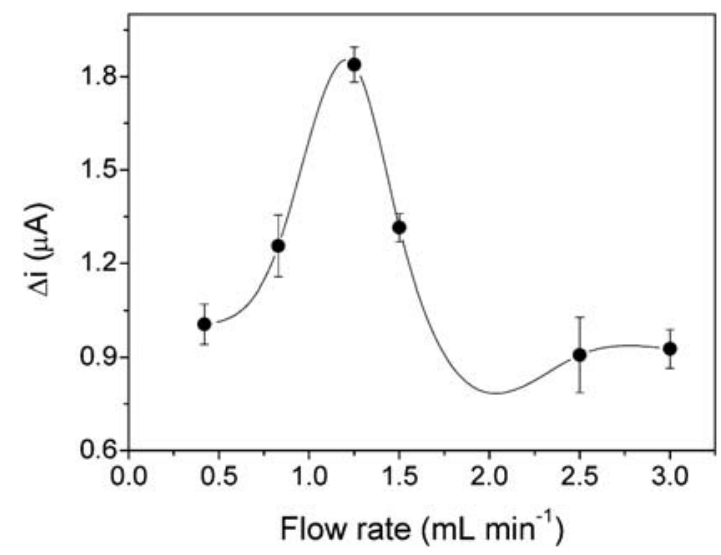

Fig. 3 Effect of the flow rate on the response to $1.0 \times 10^{-4} \mathrm{~mol} \mathrm{~L}^{-1}$ paracetamol, with $V_{\mathrm{i}}$ of $75 \mu \mathrm{L}$, and using a $0.1 \mathrm{~mol} \mathrm{~L}^{-1}$ acetate buffer at $\mathrm{pH} 3.6$ as carrier. The error bars correspond to the standard deviation for seven replicates. 


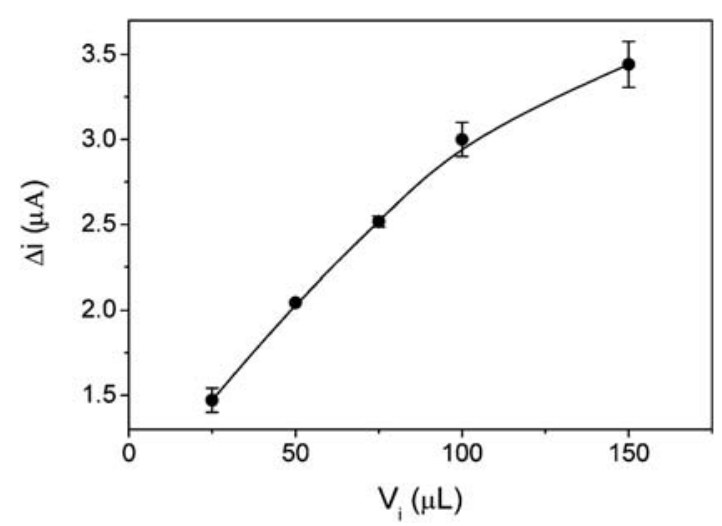

Fig. 4 Effect of injected sample volume $\left(V_{\mathrm{i}}\right)$ on the response to $4.0 \times$ $10^{-4} \mathrm{~mol} \mathrm{~L}^{-1}$ paracetamol. The experiments were carried out with $0.1 \mathrm{~mol}$ $\mathrm{L}^{-1}$ acetate buffer at $\mathrm{pH} 3.6$ as carrier, with a flow rate of $1.25 \mathrm{~mL} \mathrm{~min}^{-1}$ and applying a potential of $500 \mathrm{mV} v s$. $\mathrm{Ag} \mid \mathrm{AgCl}$. The error bars correspond to the standard deviation for seven replicates.

response mechanism of the sensor to be characteristic of a typical catalytic electro-oxidation (chemical/electrochemical). ${ }^{38,48}$ Therefore an optimized flow rate of $1.25 \mathrm{~mL} \mathrm{~min}^{-1}$ was used.

The effect of the injected sample volume $\left(V_{\mathrm{i}}\right)$ on the sensor response was studied. The signal response (Fig. 4) increased with increasing $V_{\mathrm{i}}$, perhaps related to a longer sample contact time with the catalytic zone of the biomimetic sensor. However, at higher sample volume a lower analytical frequency and lower measurement repeatability were obtained; as evaluated by the standard deviation for seven replicates. A $V_{\mathrm{i}}$ of $75 \mu \mathrm{L}$ was therefore selected, on the basis of better repeatability.

\section{Analytical characteristics of the proposed FIA system}

Fig. 5 presents the FIA signals as a function of paracetamol concentration under optimized conditions, and it can be

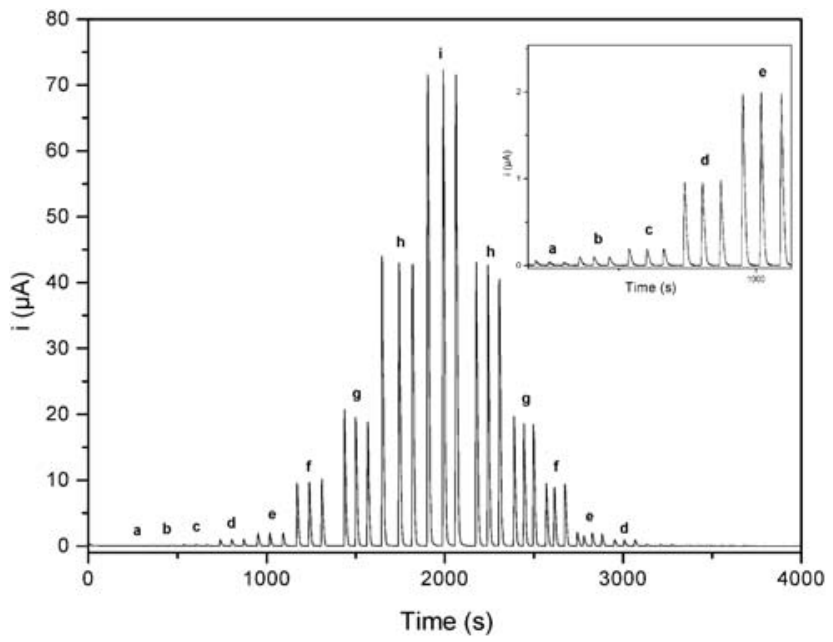

Fig. 5 FIA signals obtained for a biomimetic sensor under flow conditions for different paracetamol analyses. Experimental conditions: $V_{\mathrm{i}}=$ $75 \mu \mathrm{L}, 0.1 \mathrm{~mol} \mathrm{~L}^{-1}$ acetate buffer at $\mathrm{pH} 3.6\left(1.25 \mathrm{~mL} \mathrm{~min}^{-1}\right)$ and applied potential of $500 \mathrm{mV} v$ s. $\mathrm{Ag} \mid \mathrm{AgCl}$. [Paracetamol]: $a=1.0 \times 10^{-5} \mathrm{~mol} \mathrm{~L}^{-1}$; $b=5.0 \times 10^{-5} \mathrm{~mol} \mathrm{~L}^{-1} ; c=1.0 \times 10^{-4} \mathrm{~mol} \mathrm{~L}^{-1} ; d=5.0 \times 10^{-4} \mathrm{~mol} \mathrm{~L}^{-1}$; $e=1.0 \times 10^{-3} \mathrm{~mol} \mathrm{~L}^{-1} ; f=5.0 \times 10^{-3} \mathrm{~mol} \mathrm{~L}^{-1} ; g=1.0 \times 10^{-2} \mathrm{~mol} \mathrm{~L}^{-1}$; $h=2.5 \times 10^{-2} \mathrm{~mol} \mathrm{~L}^{-1} ; i=5.0 \times 10^{-2} \mathrm{~mol} \mathrm{~L}^{-1}$.

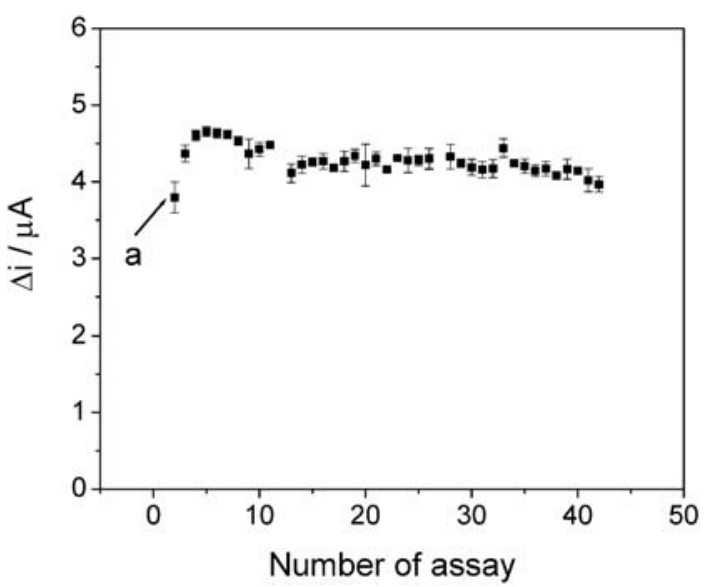

Fig. 6 Relative response obtained for $1.0 \times 10^{-3} \mathrm{~mol} \mathrm{~L}^{-1}$ paracetamol at an applied potential of $500 \mathrm{mV} v \mathrm{~s} . \mathrm{Ag} \mid \mathrm{AgCl}$, as a function of the number of assays. (a) Conditioning of the system. Each point corresponds to an average of eight injections.

observed that there is no memory effect for the sensor response. The analytical curve obtained from the data in Fig. 5 showed a wide linear response range, from $1.0 \times 10^{-5}$ to $5.0 \times 10^{-2} \mathrm{~mol}$ $\mathrm{L}^{-1}$, described by

$$
\Delta \mathrm{i}=2702( \pm 77)[\text { Paracetamol }]+0.02( \pm 0.01)
$$

with a correlation coefficient of $0.9997(n=9)$, where the current variation, $\Delta \mathrm{i}$, is given in $\mu \mathrm{A}$ and the paracetamol concentration [Paracetamol] in $\mathrm{mol} \mathrm{L}^{-1}$. It is important to emphasize that the linear response range shown by the proposed system is wider than that of other FIA systems reported in the literature, where spectroanalytical ${ }^{41,49-51}$ or electroanalytical ${ }^{14,32}$ methods were employed.

Detection and quantification limits, determined from the standard deviation of ten independent measurements of the blank in accordance with IUPAC recommendations, ${ }^{52}$ were $1.04 \times 10^{-6} \mathrm{~mol} \mathrm{~L}^{-1}$ and $3.46 \times 10^{-6} \mathrm{~mol} \mathrm{~L}^{-1}$, respectively. The

Table 2 FIA system analytical parameters obtained for paracetamol determination using the biomimetic sensor based on the FeTPyPz catalyst

\begin{tabular}{lc}
\hline Parameter & Response \\
\hline Applied potential vs. & $0.5 \mathrm{~V}$ \\
$\quad \mathrm{Ag} \mid \mathrm{AgCl}\left(\mathrm{KCl}_{\mathrm{sat}}\right)$ & \\
Flow rate $/ \mathrm{mL} \mathrm{min}^{-1}$ & 1.25 \\
$\mathrm{~V}_{\mathrm{i}} / \mu \mathrm{L}$ & 75 \\
$\mathrm{Linear}$ range $/ \mathrm{mol} \mathrm{L}^{-1}$ & $1.0 \times 10^{-5}-5.0 \times 10^{-2}$ \\
Sensitivity $/ \mu \mathrm{A} \mathrm{L} \mu \mathrm{mol}^{-1}$ & $2579 \pm 129$ \\
Quantification limit $/ \mu \mathrm{mol} \mathrm{L}^{-1}$ & 3.5 \\
Detection limit $/ \mu \mathrm{mol} \mathrm{L}^{-1}$ & 1.0 \\
Measurement repeatability $(\mathrm{RSD}, n$ & $1.2 \%$ \\
$\quad=7$ and $[$ Paracetamol] $=4.0 \times$ & \\
$\quad 10^{-4}$ mol $\left.\mathrm{L}^{-1}\right)$ & \\
Reproducibility in the construction & $5.0 \%$ \\
$\quad$ of the sensors $(\mathrm{RSD}, n=3)$ & 320 measurements or 5 days (kept \\
Operational stability & $93 \%$ of the initial signal) \\
Analytical frequency & 51 samples $\mathrm{h}^{-1}$ \\
\hline
\end{tabular}


Table 3 Determination of paracetamol in pharmaceutical formulations using the proposed FIA system, and the chromatographic method as reference

\begin{tabular}{|c|c|c|c|c|}
\hline \multirow[b]{2}{*}{ Sample } & \multirow[b]{2}{*}{ Label value } & \multicolumn{2}{|l|}{ Experimental value } & \multirow[b]{2}{*}{ Error $(\%)$} \\
\hline & & Comparative method (HPLC) & Proposed sensor & \\
\hline Tylenol $^{\circledR}$ (LFL121, 04/11) & $200 \mathrm{mg} \mathrm{mL}^{-1}$ & 190 & 196 & +3.2 \\
\hline Paracetamol (L0804193, 08/10) & $200 \mathrm{mg} \mathrm{mL}^{-1}$ & 197 & 203 & +3.0 \\
\hline Tylenol $^{\circledR}$ (LFL169, 04/10) & $160 \mathrm{mg} / 5 \mathrm{~mL}$ & 162 & 163 & +0.6 \\
\hline Tylenol $^{\circledR}$ (LAL008, 11/09) & $100 \mathrm{mg} \mathrm{mL}^{-1}$ & 92 & 96 & +4.3 \\
\hline Tylenol DC (LCL008, 01/11) & $500 \mathrm{mg} /$ tablet & 500 & 488 & -2.4 \\
\hline Tylenol AP (LFL105, 02/10) & $650 \mathrm{mg} /$ tablet & 656 & 680 & +3.6 \\
\hline Paracetamol (L15655, 05/10) & $750 \mathrm{mg} /$ tablet & 765 & 800 & +4.6 \\
\hline
\end{tabular}

detection limit value is lower than that obtained for another biosensor for paracetamol, based on the HRP enzyme. ${ }^{32}$

The repeatability of the biomimetic sensor was investigated for injections of $4.0 \times 10^{-4} \mathrm{~mol} \mathrm{~L}^{-1}$ paracetamol solution, and the relative standard deviation between injections was $1.2 \%(n=7)$. Under these conditions, the biosensor can be operated with an analytical frequency of 51 injections $\mathrm{h}^{-1}$. The FIA system reproducibility was evaluated by comparison of the sensitivities obtained using three sensors prepared on different days. The RSD value obtained was $5.0 \%$, the same as that obtained for the sensor in batch mode.

Finally, Fig. 6 shows the operational stability of the sensor under flow conditions. This parameter was investigated using eight consecutive injections of $1.0 \times 10^{-3} \mathrm{~mol} \mathrm{~L}^{-1}$ paracetamol standard solution, every $30 \mathrm{~min}$ for $4 \mathrm{~h}$ each day, over a 5 day period, totaling 64 injections per day or 320 injections over the 5 days of the evaluation. During this time the sensor presented the same response.

The flow was maintained during periods when no injection was carried out, in order to evaluate the resistance of the film on the electrode surface. After 5 days the film was still firmly adhered to the electrode surface, with no change in its appearance. This is

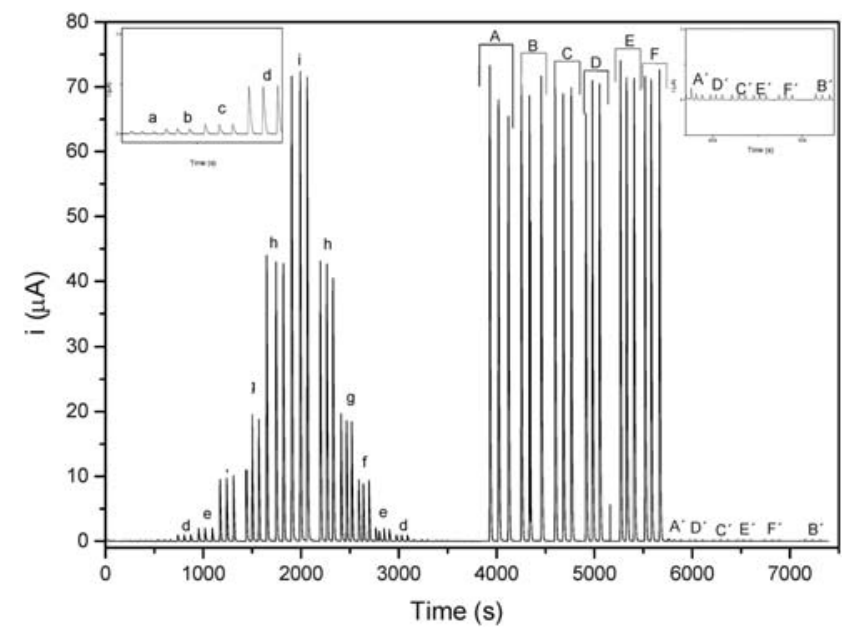

Fig. 7 FIA responses obtained for the sensor calibration and for measurements of the six river waters enriched with paracetamol at two levels of concentration. A-F: $5.0 \times 10^{-2} \mathrm{~mol} \mathrm{~L}^{-1}$ paracetamol; $\mathrm{A}^{\prime}-\mathrm{F}^{\prime}: 1.0$ $\times 10^{-4} \mathrm{~mol} \mathrm{~L}^{-1}$ paracetamol. A and $\mathrm{A}^{\prime}$ : Tietê river at the Usina da Barra club; $\mathrm{B}$ and $\mathrm{B}^{\prime}$ : Tietê river on the outskirts of Igaraçu city; $\mathrm{C}$ and $\mathrm{C}^{\prime}$ : Tietê river by the bridge in Barra Bonita city; $\mathrm{D}$ and $\mathrm{D}^{\prime}$ : Jacaré Guaçú; $\mathrm{E}$ and $\mathrm{E}^{\prime}$ : Jacaré Pepira; $\mathrm{F}$ and $\mathrm{F}^{\prime}$ : Jaú. [Paracetamol]: the same as a-i in Fig. 5. important, since an ability for at least eight hours continuous monitoring is often required of automated methodologies.

The analytical parameters for paracetamol quantification using the FIA system are shown in Table 2. All characteristics demonstrate the viability of the application of this biomimetic sensor for determination of paracetamol in pharmaceutical formulations, and in environmental and industrial samples.

\section{Application}

The application of the proposed sensor was tested in a similar way to the batch mode, ${ }^{38}$ using two different sample types. The first type, the commonest, were the seven commercial formulations. The second type were the river water samples, which were enriched with paracetamol at two levels of concentration in order to demonstrate the applicability of the proposed FIA system to environmental samples.

Table 3 shows the results obtained for the determination of paracetamol in the commercial formulations. The concentrations were determined by the FIA system using the external calibration method, and compared with those obtained with the official chromatographic method. The results were not significantly different, at a confidence level of $95 \%$, suggesting that the proposed methodology is an efficient and rapid alternative for paracetamol analyses.

Fig. 7 shows the response profile obtained for analyses of the six river water samples enriched with paracetamol at two concentration levels. It can be seen in Table 4 that very good recoveries were obtained, with values close to $100 \%$ and near those obtained with the HPLC method.

Table 4 Recovery values obtained with the proposed FIA system for paracetamol in water from rivers

\begin{tabular}{lll}
\hline & \% Recovery & \\
\cline { 2 - 3 } River & FIA $^{a}$ & HPLC \\
\hline Jacaré Pepira & $100.0 \pm 2.0$ & 96 \\
Jacaré Guaçú & $96.4 \pm 3.6$ & 94 \\
Jaú & $99.8 \pm 1.3$ & 96 \\
$\begin{array}{l}\text { Tietê river on the outskirts of } \\
\text { Igaraçu city }\end{array}$ & $97.8 \pm 1.9$ & 94 \\
$\begin{array}{l}\text { Tietê river by the bridge in Barra } \\
\text { Bonita city }\end{array}$ & $96.9 \pm 0.5$ & 94 \\
$\begin{array}{l}\text { Tietê river at the Usina da Barra } \\
\text { club }\end{array}$ & $95.8 \pm 5.6$ & 92 \\
$\begin{array}{l}\text { a Average of recovery values for the two concentration levels. } \\
\text { An }\end{array}$ & \\
\hline
\end{tabular}




\section{Conclusions}

This work describes for the first time the determination of paracetamol using a biomimetic sensor as a sensitive and selective detector within a flow injection system. The FIA arrangement presents a wide response range and high sensitivity, and was satisfactorily applied to the analysis of commercial pharmaceutical formulations. It was also demonstrated that the drug can be quantified in aqueous samples, such as river water.

\section{Acknowledgements}

The authors gratefully acknowledge financial support from FAPESP. MCQO is indebted to FAPESP for a fellowship. The authors acknowledge Profa. Dra. Mary Rosa Rodrigues de Marchi and Mr. Thiago Bernardo Cavassani from GRESCO (IQCAr-UNESP) for instruction in use of the HPLC technique.

\section{References}

1 B. Halling-Sorensen, S. N. Nielsen, P. F. Lanzky, F. Ingerslev, H. C. H. Lutzhoft and S. E. Jorgensen, Chemosphere, 1998, 36, 357-393.

2 J. P. Bound and N. Voulvoulis, Chemosphere, 2004, 56, 1143-1155.

3 C. G. Daughton, Environ. Impact Assess. Rev., 2004, 24, 711-732.

4 T. Heberer, Toxicol. Lett., 2002, 131, 5-17.

5 M. Stumpf, T. A. Ternes, R. D. Wilken, S. V. Rodrigues and W. Baumann, Sci. Total Environ., 1999, 225, 135-141.

6 R. Céspedes, S. Lacorte, D. Raldú, A. Ginebreda, D. Barceló and B. Piña, Chemosphere, 2005, 61, 1710-1719.

7 D. Bendz, N. A. Paxéus, T. R. Ginn and F. J. Loge, J. Hazard. Mater., 2005, 122, 195-204.

8 N. Lindqvist, T. Tuhkanen and L. Kronberg, Water Res., 2005, 39, 2219-2228.

9 R. Andreozzi, R. Marotta and N. Paxéus, Chemosphere, 2003, 50, 1319-1330.

10 M. D. Hernando, M. Mezcua, A. R. Fernández-Alba and D. Barceló, Talanta, 2006, 69, 334-342.

11 K. Fent, A. A. Weston and D. Caminada, Aquat. Toxicol., 2006, 76, 122-159.

12 M. L. Ramos, J. F. Tyson and D. J. Curran, Anal. Chim. Acta, 1998, 364, 107.

13 F. S. Felix, C. M. A. Brett and L. Angnes, J. Pharm. Biomed. Anal., 2007, 43, 1622.

14 D. Loffler, J. Rombke, M. Meller and T. A. Ternes, Environ. Sci. Technol., 2005, 39, 5209.

15 F. L. Martin and A. E. McLean, Drug Chem. Toxicol., 1998, 21, 477.

16 C. A. Mugford and J. B. Tarloff, Toxicol. Lett., 1997, 93, 15.

17 H. T. Nagasawa, D. W. Shoeman, J. F. Cohen and W. B. Rathbun, J. Biochem. Toxicol., 1996, 11, 289.

18 M. K. Srivastava, S. Ahmed, D. Singh and I. C. Shukala, Analyst, $1985,110,735$.

19 Z. Boushsain, S. Garrigues, A. Morales-Rubio and M. de la Guardia, Anal. Chim. Acta, 1996, 330, 59.
20 G. Amann, G. Gubitz, R. W. Frei and W. Santi, Anal. Chim. Acta, 1980, 116, 119.

21 K. Molt and M. Egelkraut, GIT Fachz. Lab., 1988, 32, 1311

22 T. H. King, C. K. Mann and T. J. Vickers, J. Pharm. Sci., 1985, 74, 443.

23 Z. Boushsain, S. Garrigues and M. de la Guardia, Analyst, 1996, 121, 635.

24 M. A. Evans and R. D. Harbinson, J. Pharm. Sci., 1977, 66, 1628.

25 A. Ivaska and T. H. Ryan, Collect. Chem. Commun, 1981, 46, 2865.

26 M. L. Ramos, J. F. Tyson and D. J. Curran, Anal. Chim. Acta, 1998, 364, 107.

27 M. J. Stewart, P. I. Adriaenssens, D. R. Jarvie and L. F. Prescott, Ann. Clin. Biochem, 1979, 16, 89.

28 A. N. Papas, M. Y. Alpert, S. M. Marchese and J. W. Fitzgerald, Anal. Chem., 1985, 57, 1408.

29 I. I. Koukli, A. C. Calokerinos and T. P. Hadjiioannou, Analyst, 1989, 114, 711.

30 A. G. Alapont, L. L. Zamora and J. M. Calatayud, J. Pharm. Biomed. Anal., 1999, 21, 311.

31 K. Vandyke, M. Sacks and N. Qazi, J. Biolumin. Chemilumin., 1998, 13, 339.

32 I. C. Vieira, K. O. Lupetti and O. Fatibello-Filho, Quim. Nova, 2003, 26, 39 .

33 O. Fatibello-Filho, K. O. Lupetti and I. C. Vieira, Talanta, 2001, 55, 685.

34 J. Wang, T. Golden and P. Tuzhi, Anal. Chem., 1987, 59, 740.

35 P. Masawat, S. Liawruangrath, Y. Vaneesorn and B. Liawruangrath, Talanta, 2002, 58, 1221.

36 W. Peng, T. Li, H. Li and E. Wang, Anal. Chim. Acta, 1994, 298, 415.

37 G. A. Messina, I. E. De Vito and J. Raba, Anal. Chim. Acta, 2006, 559, 152.

38 M. D. P. T. Sotomayor, A. Sigoli, M. R. V. Lanza, A. A. Tanaka and L. T. Kubota, J. Braz. Chem. Soc., 2008, 19, 734.

39 J. Ruzicka and E. H. Hansen, Anal. Chim. Acta, 1975, 78, 145.

40 P. Cervini and E. T. G. Cavalheiro, J. Braz. Chem. Soc., 2008, 19, 836.

41 A. D. Vidal, P. O. Barrales and A. M. Díaz, Microchim. Acta, 2003, 141, 157.

42 A. A. Tanaka, C. Fierro, D. A. Scherson and E. Yeager, Mater. Chem. Phys., 1989, 22, 431.

43 P. Calvo-Marzal, S. S. Rosatto, P. A. Granjeiro, H. Aoyama and L. T. Kubota, Anal. Chim. Acta, 2001, 441, 207.

44 H. Bergamin, F. J. X. Medeiros, B. F. Reis and E. A. G. Zaggatto, Anal. Chim. Acta, 1978, 101, 9.

45 G. Lunn; HPLC-Methods for Pharmaceutical Analysis, John Wiley \& Sons, Inc.: New York, 2000, vol. 1.

46 M. Sono, M. P. Roach, E. D. Coulter and J. H. Dawson, Chem. Rev., 1996, 96, 2841.

47 S. S. Rosatto, M. P. T. Sotomayor, L. T. Kubota and Y. Gushikem, Electrochim. Acta, 2002, 47, 4451.

48 A. J. Bard and L. R. Faulkner; Electrochemical Methods: Fundamentals and Applications, 2nd ed., John Wiley \& Sons, Inc.: New York, 2001.

49 M. J. A. Cañada, M. I. P. Reguera, A. R. Medina, M. L. F. Córdova and A. M. Díaz, J. Pharm. Biomed. Anal., 2000, 22, 59.

50 J. A. M. Pulgarin and L. F. G. Bermejo, Anal. Chim. Acta, 1996, 333, 59.

51 W. T. Suarez, H. J. Vieira and O. Fatibello-Filho, Eclética Quim, 2005, 30, 21.

52 A. Currie, Anal. Chim. Acta, 1999, 391, 105. 